\title{
KUOLLEESTA YLEISÖSTÄ \\ TUKEVAAN JA ARVOSTAVAAN \\ YLEISÖÖN - YLEISÖN MERKITYS \\ JA ROOLI JAZZISSA
}

Kerätessäni materiaalia viimeistelyvaiheessa olevaan jazzmuusikoiden flow-kokemuksia käsittelevään väitöskirjatutkimukseeni törmäsin usein keskusteluihin yleisön merkityksestä muusikoille. Keskusteluja leimasi kuitenkin eräänlainen ristiriita, jossa korostettiin sekä yleisön toissijaista merkitystä että yleisön keskeisyyttä esityksen kannalta. Nämä keskustelut osoittivat selkeästi, että yleisöllä on varsin moninainen merkitys esityksen ja esiintyjän näkökulmasta katsottuna. Irmeli Niemi (1995: 29) onkin osuvasti todennut, että esitys vaatii toteutuakseen yleisön läsnäoloa. Ilman yleisöä tilanne muuttuu harjoitukseksi tai muusikoiden keskinäiseksi hauskanpidoksi.

Yleisön keskeisestä roolista huolimatta jazzin tutkimuksen parissa on esiintyjien ja yleisön väliseen vuorovaikutukseen kiinnitetty äärimmäisen vähän huomiota, vaikkakin aiheeseen liittyvää kommentointia löytyy sivulauseissa lähes kaikista muusikkoutta käsittelevistä tutkimuksista. Syvemmän keskustelun puuttuessa koin aiheen vaativan lähempää tarkastelua. Pyrinkin tämän artikkelin kautta tarkastelemaan yleisön roolia lähemmin. Artikkelin tutkimuskysymykset ovat seuraavat: Minkälainen merkitys yleisöllä on esiintyjälle? Miten esiintyjä suhtautuu yleisöön? Miten yleisö vaikuttaa esiintyjään ja esitykseen?

Tutkimukseni perustuu sekä jazzmuusikoiden haastatteluihin että jazzissa käytettyjen esiintymispaikkojen havainnointiin. Haastatellut muusikot edustavat jazzia kaikessa laaja-alaisuudessaan tyylilajien kirjon kulkiessa swingistä free jazziin 
ja traditionaalisesta "mainstreamista"' progressiiviseen jazziin. Keskeisenä tekijänä haastateltavien valinnassa oli heidän oma identifioitumisensa jazziin sekä heidän täysipäivänen ammatillinen kytköksenä jazzin kenttään. Suurin osa haastatelluista muusikoista ansaitsi koko toimeentulonsa jazzin soittamisesta. Muutamat hankkivat lisätuloja opettamisesta ja soitinkorjausten tekemisestä.

Haastatelluiden muusikoiden esiintymiset vaihtelivat suuresti. Esimerkiksi Lontoossa suurin osa haastatelluista muusikoista teki keikkoja, joista osa edusti muusikon omia taiteellisia päämääriä, kun taas osan taustalla olivat täysin välineelliset tavoitteet eli elannon ansaitseminen. Osa haastatelluista taas oli musiikillisesti saavuttanut sellaisen aseman, että he pystyivät valikoimaan esiintymisiään säilyttäen näin omat taiteelliset päämääränsä. Iältään haastatellut muusikot vaihtelivat kolmestakymmenestä kuuteenkymmeneen ikävuoteen. Jazzin miesvaltaisuus näkyy myös haastatteluaineistossa, sillä kahdeksastatoista haastatellusta muusikosta vain kaksi oli naisia.

Lähemmän havainnoinnin kohteena oli seitsemän esiintymispaikkaa, joista kaksi sijaitsi Jyväskylässä ja viisi Lontoossa. Esiintymispaikat vaihtelivat väliaikaisista museoihin ja ravintoloihin rakennetuista tiloista pubeihin ja perinteisiin jazzklubeihin. Keikoilla esitetty musiikki edusti niin progressiivista kvartettijazzia, traditionaalista triosoittamista, funkvaikutteista kvintettijazzia kuin swing-pohjaista septettimusisointia. Havainnoinnit tapahtuivat syyskuun 2006 ja tammikuun 2008 välillä. Havainnoituja esiintymispaikkoja ja niiden fyysisiä rajoitteita olen tarkastellut lähemmin kirjoittajan toisessa artikkelissa (ks. Hytönen 2008).

\section{Metodiset välineet: diskurssianalyysi ja tulkitseva fenomenologinen analyysi}

Käytän aineiston analyysissä kahta toisiaan täydentävää analyysivälinettä; diskurssianalyysiä ja tulkitsevaa fenomenologista analyysiä. Koska optimaalisia kokemuksia käsittelevät tutkimukset keskittyvät suurimmaksi osaksi psykologiaan, tulevat tämänkin tutkimuksen taustalla vaikuttavat teoriat ja analyysivälineet lähinnä psykologian parista. Tästä painotuksesta johtuen artikkelissa on käytetty diskurssianalyysin monista erilaisista lähestymistavoista erityisesti diskursiivista psykologiaa. Jaottelun pohjalla on psykologi Carla Willigin (2003: 159-160) näkemys diskurssianalyysin kahdesta eri versiosta: diskursiivinen psykologia (discursive psychology) 
ja foucaultilainen diskurssianalyysi. Kumpikin suuntaus on kiinnostunut kielen roolista sosiaalisen todellisuuden rakentajana, mutta suuntausten taustalla vallitsevat erilaiset teoreettiset perinteet, ja lisäksi ne käyttävät erilaisia tutkimuskysymyksiä.

Kun foucaltlainen diskurssianalyysi kysyy miten diskurssi rakentaa subjektia ja objektia, diskursiivinen psykologia keskittyy siihen mitä osallistujat tekevät puheellaan. Jos foucaultlainen diskurssianalyysi näkee että diskurssit rakentavat subjektejaan, on puhuja diskursiivisen psykologian näkökulmasta aktiivinen agentti, joka käyttää diskursseja työvälineinään. (Willig 2003: 164, 172, 182.) Diskursiivinen psykologia pohjaa alun perin Potterin ja Wetherellin kirjaan Discourse and Social Psychology (1987), mutta diskursiivisen psykologian nimike on annettu vasta myöhemmin (Willig 2003: 159-160). Diskurssianalyysin yleisenä päämääränä on tutkia kuinka kieli rakentaa ja luo sosiaalista vuorovaikutusta ja monimuotoistaa sosiaalista maailmaa. Diskurssianalyysin mukaan sosiaalisilla teksteillä on rakentava rooli ihmisten sosiaalisessa elämässä (Potter \& Wetherell 1987: 1-2).

Potter, Stringer ja Wetherell ovat todenneet, että vaikkakin tekstit - jotka voivat sisältää kirjoitusta ja keskusteluja - on tyypillisesti nähty ongelmattomina tiedon lähteinä, ne luonnollistavat väistämättä kohdettaan. Tekstit saavat meidät uskomaan, että asiat ovat niin kuin ne esitetään. Tällainen realistinen tai kuvaileva tapa katsoa tekstejä ei kuitenkaan aina riitä. Diskurssianalyysi näkeekin tekstit monimutkaisina kulttuurillisina ja psykologisina tuotteina. Tekstit rakennetaan tiettyä tapaa noudattaen, jotta asioita saataisiin tapahtumaan.

Diskurssianalyysi yrittääkin katsoa tekstin välittömän sisällön taakse tai ylitse ja selvittää miten tekstin merkitys tosiasiassa tuotetaan. Merkitys ei siis ole tekstissä itsessään vaan se on tietyn kontekstisidonnaisen luennan tulosta. (Potter, Stringer \& Wetherell 1984: 2-3, 77.)

Diskursiivisessa psykologiassa ajatellaan, että lausuessaan mielipiteitään tai uskomuksiaan ääneen ihmiset osallistuvat keskusteluun. Tällä keskustelulla on jokin päämäärä ja keskusteluun osallistujilla on jonkinlainen osuus siinä. Selkokielellä sanottuna tämä tarkoittaa, että saadaksemme selvää mitä ihmiset sanovat meidän täytyy ottaa huomioon se sosiaalinen konteksti jonka sisällä he puhuvat. (Willig 2003: 161.)

Tulkitseva fenomenologinen analyysi, eli Interpretative Phenomenological Analysis (tästä eteenpäin IPA), taas pyrkii tutkimaan osallistujien maailmankuvaa ja omaksumaan mahdollisimman hyvin jonkin ryhmän jäsenten näkökulman tutkitusta ilmiöstä (Smith 1996: 263). IPA:ta käytetäänkin yleensä, kun halutaan tietää tietyn 
tapahtuman, kokemuksen tai tilan merkitys osallistujille (Smith \& Osborn 2003: 51). IPA:n kautta tutkija sitoutuu teoreettisella tasolla ihmisiin kognitiivisina, lingvistisinä, affektiivisina ja fyysisinä olentoina. Näkemyksen mukaan ihmisten puheen, ajattelun ja emotionaalisen tilan välillä on yhteys, vaikkakin tämä yhteys on monimutkainen. Ihmisten mentaalisen ja emotionaalisen tilan saavuttaminen riippuu myös tutkijan kapasiteetista tulkita puhetta. Tähän käytetään välineenä syvällistä laadullista analyysiä. (Smith \& Osborn 2003: 52.)

Diskurssianalyysin ja IPA:n yhdistäminen ei ole ongelmatonta, mutta kuten Johnson, Chambers, Raghuram ja Tincknell (2004: 43-44) ovat todenneet, metodit tuottavat useimmiten parasta materiaalia kun niiden sääntöjä ja konventioita ylitetään ja yhdistetään. Diskurssianalyysin ja IPA:n välillä on nähtävissä kuitenkin selkeitä linkkejä, sillä IPA kehitettiin alun perin 1990-luvun puolivälissä brittiläisessä sosiaalipsykologiassa kahden eri näkökulman, sosiaalisen kognition (social cognition) ja diskurssianalyysin välittäjäksi. Smith haki uuden analyysimetodin kautta myös välinettä, joka auttaisi diskurssianalyysiä paremmin psykologeja ymmärtämään esimerkiksi terveydentilaa koskevien uskomusten ja käytöksen välistä suhdetta. Smith näki IPA:n myös käytännöllisenä välineenä kahden vastakkaisen näkökulman yhteen tuomisessa. Eri näkökulmat eivät kuitenkaan sulje toisiaan pois ja Smithin mukaan IPA:ta ja diskurssianalyysiä voidaan käyttää myös hedelmällisessä vuorovaikutuksessa. (Smith 1996: 261-264.) Pidänkin tästä syystä diskurssianalyysiä ja IPA: ta toisiaan täydentävinä metodeina, joita voidaan käyttää yhdessä ilman suurempia teoreettisia ristiriitoja.

Kahden eri metodin käyttämisen taustalla on ajatus eri metodien erilaisten painotusten tuomasta vahvuudesta. Katson että nämä kaksi metodia antavat erilaisia näkökulmia tutkittavaan aiheeseen ja täyttävät samalla toistensa jättämiä puutteita. Diskurssianalyysin huomioidessa vuorovaikutusta ja kokemusten tuottamista puheessa IPA tarkastelee ajatusten ja emootioiden ilmaisua ja paljastaa osallistujien emotionaalisen ja mentaalisen tilan. Laajempaa aineistoani tarkasteltaessa diskurssianalyysi mahdollistaa sen huomioimisen miten flowsta käytäviä diskursseja käytetään imagon ja identiteetin rakentamiseen, kun taas IPA antaa välineet kokemusten emotionaalisen merkityksen ja motivaation jäljittämiseen. Kun diskurssianalyysi katsoo puheen laajempaa kontekstia käytetyn diskurssin kautta, IPA keskittyy tutkimaan käytettyjä sanoja ja lausahduksia sekä niiden takana olevia emootioita.

Tätä artikkelia lukiessa tulee kuitenkin ottaa huomioon, että kyseessä on laajemmasta aineistosta irrotettu yksittäinen teema. Tästä johtuen esimerkiksi diskurssi- 
analyysi ei tuo esille tämän artikkelin yhteydessä kaikkia aineistossa esiintyviä diskursseja, vaan tarkastelu keskittyy aiheeseen liittyviin diskursseihin. Painotan diskurssianalyysiä, joka tuottaa määrällisesti laajempaa aineistoa kuin IPA.

\section{Muusikon ja yleisön suhde aikaisemmassa kirjallisuudessa}

Jazzia käsittelevän kirjallisuuden parissa yleisöstä on kirjoitettu varsin vähän ja useimmiten kirjoitukset ovat eräänlaisten legendojen ja tarinoiden toistelua. Esimerkkinä tästä voidaan pitää esimerkiksi Paul Berlinerin (1994: 257) mainitsemaa tarinaa kuinka trumpetisti Clark Terry oli eräässä esityksessä reagoinut keikkapaikalta ulos kävelleeseen yleisön jäseneen soittamalla sordiinon kanssa selkeästi sanat: "Go on home! Go on home!" Terry oli saanut näin paikalle jääneen yleisön nauramaan. Tämän tyyppisiä tarinoita jazzin historia on pullollaan ja nämä tarinat kertovat osaltaan muusikkojen parissa vallitsevasta suhtautumisesta yleisöön ja esiintymistilanteisiin.

Vaikka Berliner on yksi ainoita yleisöstä laajemmin kirjoittaneita jazzin tutkijoita, käsitellään hänenkin kirjassaan aihetta vain muutamissa alaluvuissa. Berliner on kuitenkin todennut esimerkiksi yleisön koon voivan vaikuttaa muusikon kokemukseen. Suuri huone pienellä yleisömäärällä lannistaa, kun taas pieni huone täynnä yleisöä kannustaa muusikkoa. Berliner lainaa Wynton Marsalista, joka on todennut pienen huoneen voivan olla äärimmäisen hyvä esiintymispaikka, jos huoneesta löytyy hyvä yleisö ja hyvä tunnelma. Berlinerin mukaan yleisö lisää sekä esiintyjän paineita että esiintymisen palkitsevuutta. Yleisö korostaa myös musiikin hetkellisyyden tuntua. (Berliner 1994: 452, 455.)

Kari Kurkela on todennut, että vaikka yleisesti ajatellaankin yleisön olevan esityksessä saavana osapuolena, antaa esiintyminen paljon myös esiintyjälle. Tämä liittyy osaltaan esiintymiseen liittyvään sosiaaliseen vuorovaikutukseen. (Kurkela 1995: 77.) Irmeli Niemen mukaan esittäjän tunnot ja kokemukset saattavat esityksen aikana koskettaa vain muutamia ihmisiä. Kuitenkin ottamalla tämän riskin esiintyjä luo mahdollisuudet vahvan vuorovaikutustilanteen syntymiselle. (Niemi 1995: 29.)

Yleisön reaktioista muusikko voi hakea välitöntä palautetta soitolleen, mikä tukee Mihaly Csikszentmihalyin (2002: 54-58) mukaan optimaalisten kokemusten syntyä. Muusikot saavat palautetta myös yleisön aplodeista ja heidän kehon kie- 
lestään suhteessa musiikkiin (Berliner 1994: 465-466). Toisaalta kirjallisuudesta käy esille se, että yleisö vaikuttaa muusikoiden suoritukseen myös asenteidensa kautta. Steven Jeddeloh toteaa, että jos yleisö on ymmärtäväistä ja tukevaa, voi esiintyjien ja yleisön välille syntyä merkityksellinen vuorovaikutus, jossa molemmat saavat toisiltaan energiaa. Keikkatilanteissa on kuitenkin myös mahdollista, että yleisö vie välinpitämättömyydellään pohjan muusikoiden suoritukselta. (Jeddeloh 2003: 136-137.) Tällaisissa tilanteissa muusikot saattavat usein sulkea yleisö esiintymistilanteen ulkopuolelle ja soittaa vain toisilleen.

Psykologisissa tutkimuksissa on toisaalta todettu, että tuttu ja tukeva yleisö saattaa vaikuttaa esiintyjän suoritukseen negatiivisesti. Näin on etenkin jos suoritettava tehtävä on vaikea ja haastava. Butler ja Baumeister ovat todenneet tutkimuksessaan, että ihmiset jotka esiintyivät tukevan ja tutun yleisön edessä suoriutuivat tehtävistään huonommin kuin ihmiset jotka esiintyivät neutraalin tai jopa vihamielisen yleisön edessä. Paradoksinomaisesti esiintyjät itse kokivat kuitenkin suoriutuvansa tehtävistään paremmin tukevan yleisön edessä. (Butler \& Baumeister 1998: 1225.)

Osassa esiintymiseen kouluttavia oppaita korostetaan myös vuorovaikutuksen roolia. Steward Gordon esimerkiksi toteaa Mastering the Art of Performance -oppaassaan, että muusikon tulisi olla tietoinen siitä, kuinka ihmiset reagoivat, tuntevat ja ajattelevat jopa siihen pisteeseen asti, että muusikko ei vain tiedä mitä juuri tapahtui vaan on sensitiivinen sille mitä on tapahtumassa. Hänen mukaansa vuorovaikutus tuo osaltaan myös arvokkaan lisän itse esitykseen. Sensitiivisyys yleisön kanssa käytävälle vuorovaikutukselle lisää osaltaan myös esiintyjän itseluottamusta esityksen aikana ja antaa muusikolle mahdollisuuden soveltaa omaa musiikkiaan tilanteeseen sopivaksi. Tätä kautta esityksestä voidaan luoda vaikuttava. Gordonin mukaan kokeneet esiintyjät osaavatkin useimmiten ottaa yleisönsä huomioon. (Gordon 2006: 154-155.)

Howard Becker on jo 1950-luvulla todennut jazzmuusikkojen toimivan palveluammatissa, jossa "asiakas ohjaa tai yrittää ohjata työntekijää tämän toimessaan" muun muassa asettamalla tälle sanktioita (Becker 1951: 136). Käytännössä esityksessä on läsnä kaksi osapuolta, joista ensimmäisen päivittäiset aktiviteetit kietoutuvat ammatin hoitamiseen, ja jonka 'minä' on jossain määrin kiinnittynyt tähän ammattiin. Toisen osapuolen kytkös esitykseen on Beckerin mukaan paljon satunnaisempi ja välinpitämättömämpi.

Suhde yleisön ja muusikon välillä ei siis missään nimessä ole tasapuolinen. Jazzin parissa esiintymisten ympärille rakentuvat käyttäytymiskoodit ovatkin klassisen 
musiikin esittämistilanteita vapaampia ja poikkeavat osaltaan myös muiden populaarimusiikin lajien käytännöistä. Jazzkeikalla yleisö voi juoda ja toisinaan jopa syödä. Yleisö voi useimmiten kulkea vapaasti tilassa, eikä yleisö välttämättä ole tullut paikalle aktiivisesti kuuntelemaan esiintyjää kuten useimmiten on esimerkiksi popin ja rockin live-esitysten parissa.

Jazz voi olla toisinaan myös täysin taustamusiikkia ja keikat voivat olla yleisölle myös sosiaalinen tilanne jonne tullaan tapaamaan ihmisiä musiikin kuuntelun lisäksi. Kaikki nämä tekijät vaikuttavat siihen, että jazzesitys on varsin altis yleisön mielialoille ja liikkeille. Yleisön merkityksen voidaan olettaa siis korostuvan jazzin parissa. Klassisen musiikin tai rock- ja popmusiikin parissa tehtyjä yleisötutkimuksia ei näin ollen myöskään voida suoraan soveltaa jazzin pariin vaan tarvitaan omaa jazziin keskittynyttä tutkimusta. Tämä artikkeli pyrkii osaltaan avaamaan tätä keskustelua ja kenttää laajemmalle tarkastelulle.

\section{Yleisön kohtaaminen ja vuorovaikutus haastatteluissa}

Tehdessäni jazzmuusikoiden haastatteluiden analyysiä yleisön rooli nousi esille varsin vahvasti. IPA:n kautta kävi ilmeiseksi, että muusikot odottivat yleisöltään varsin paljon. Puolet haastateltavista totesi yleisön asenteen olevan erityisen tärkeää esityksen kannalta. Yleisön kiinnostus näytti olevan muusikoille tärkeää, mutta esille nousi myös yleisön esiintyjään kohdistamien odotusten tärkeys. Kaikkien näiden tekijöiden nähtiin vaikuttavan esiintymiseen. (Evans h2006: 9; Garnett h2006: 9, 20; Kaldestad h2006: 9; Lapthorn h2006: 19; Parker h2006: 10; Savolainen h2005: 13.) ${ }^{1}$.

Myös diskurssianalyysin käyttö paljasti samanlaisia painotuksia. Keskusteluissa tuotiin varsin selkeästi esille se, että esiintymiseen liittyvä "hypnoottinen tunne" ja groove syntyvät juuri yleisön läsnäolon seurauksena. Muusikoiden todettiin saavan hengen ravintonsa yleisön edessä soittamisesta. (Kaldestad h2006: 9; Lintinen h2005: 5.) Yleisön läsnäolo tekee soittamisesta merkityksellisen tilanteen. Diskurssianalyysi korosti laajemmassakin aineistossa yhteyden tunnetta jota kutsun kollektiivisuusdiskurssiksi. Kollektiivisuus itsessään voi sisältää sekä muusikoiden keskinäiset suhteet että yleisön ja muusikon välisen vuorovaikutuksen. Kollektiivisuuden voidaan katsoa positiivisesti merkityksellistävän saavutetun kokemuksen arvoa.

Muutamat muusikot totesivat yleisön olevan erityisen tärkeä tekijä juuri esiintymispaikan ilmapiirin luomisessa. Soittaminen nähtiin sosiaalisena aktiviteettina ja 
haastatteluissa mainittiin muun muassa, että ilman yleisöä soittamisesta ei pidetty kovinkaan paljon. Eräs muusikko totesi yleisöllä olevan "varsin massiivinen rooli" esityksessä. Tärkeää oli saavuttaa tunne siitä, että yleisö oli avoin muusikon energialle. Yleisöä pidettiin myös eräänlaisena ärsykkeenä, joka sai muusikon keskittymään musiikkiin. (Evans h2006: 7; Lapthorn h2006: 19; Parker h2006: 10; Uotila h2004: 2.)

Kommentit osoittavat yleisön roolin keskeisyyden. Esiintyminen nähdään aktiviteettina johon myös yleisö osallistuu aktiivisesti. Vuorovaikutus koostuu kuitenkin varsin pienistä asioista; kuunnelluksi tulemisen tunteesta ja yleisön avoimuuden kokemisesta. Yleisö osallistuu myös muusikon keskittymisen rakentamiseen ja vaikuttaa tätä kautta esitetyn musiikin laatuun. Live-esitys ei siis ole tilanne, jossa muusikko yksipuolisesti antaa ja yleisö vastaanottaa, vaan tilanne jossa molempien asenne ja käyttäytyminen vaikuttavat lopputulokseen. Tämän tyyppiset keskustelut käyttävät hyväkseen juuri kollektiivisuuden diskurssia.

Eräs brittiläinen haastateltava kuvaili yleisön roolia seuraavasti:

Ne odotukset tai, no tiedät kyllä, yleisön motivaatiolla ja intentiolla on minusta tärkeä rooli... Ja heidän käytöksensä. Jos he ovat keskittyneitä ja innostuneita, se auttaa sinua. (Parker h2006: 9, oma käännös.)

Motivaation voidaan katsoa merkitsevän tässä yhteydessä yleisön asennetta, miksi he ovat tulleet paikalle. Intentio-sana viittaa yleisön huomion keskipisteeseen, mihin keskitytään ja mikä on musiikin asema. Yleisön innostus taas viittaa optimaalisen yleisön musiikkisuhteeseen, heidän emotionaaliseen sitoutumiseensa esitettävään musiikkiin.

Samansuuntaisia ajatuksia oli nähtävissä myös muissa haastatteluissa. Yhdysvaltalainen haastateltava totesi soittaneensa aikoinaan Shirley Hornin kanssa isoilla lavoilla. Hän kertoi nauttineensa tällöin erityisesti tunteesta, että sai soittaa tuhansille ihmisille, jotka "olivat tulleet katsomaan sitä musiikkia, koska he rakastivat sitä". Tällaisessa ympäristössä muusikko pystyi uppoutumaan työhönsä täysin. (Janisch h2006: 8.) Tämän lainauksen painotus on yleisön asenteessa. Ideaalilla yleisöllä on vahva emotionaalinen side, "rakkaus", kyseiseen musiikkiin. Kommentti myös sisältää ajatuksen muusikon varauksettomasta hyväksynnästä. Edellisten kommenttien voidaan nähdä käyttävän hyväkseen emotionaalisuusdiskurssia, jossa korostetaan tunteiden ja emootioiden keskisyyttä, kuten myös emotionaalista sitoutumista musiikkiin. 
Haastatteluissa keskusteltiin tämän lisäksi paljon juuri yleisön asenteen ja käytöksen tärkeydestä. Erään muusikon mielestä esiintyjä "oppi aistimaan" erot yleisöjen välillä. Optimaalisena hän piti muun muassa yleisöä, joka osallistui muusikon toimintaan ja osoitti jollakin tasolla "varauksetonta hyväksyntää" muusikkoa kohtaan. Yleisön avoimuuden ja vastaanottavaisuuden pystyi näkemään näiden silmistä. Häiritsevälle yleisölle soittaminen taas sai muusikon odottamaan illan päättymistä. (Savolainen h2005: 13.)

Tämän tyyppiset kommentit näyttäisivät osoittavan yleisön asenteen ja käytöksen vaikuttavan aktiivisesti muusikon suoritukseen ja hyvien soittokokemusten muodostumiseen. Hyvä yleisö nähdään hyväksyvänä, osallistuvana ja musiikkiin keskittyvänä. Yleisö jakaa muusikon kanssa kokemuksen musiikin tärkeydestä. Kommentti osoittaa myös sen, että muusikko kiinnittää huomiota yleisön visuaalisiin vihjeisiin ja vuorovaikutukseen esityksen aikana. Samanaikaisesti huomautus yleisön "aistimisesta" viittaa muusikon intuitiiviseen tietoon yleisön asenteesta. Viittaukseen liittyy kuitenkin ajatus taidon oppimisesta, millä annetaan ymmärtää että tämä intuitiivinen taito saadaan kokemuksen ja ammattitaidon kautta. Viittaukset ammattitaitoon tuovat keskusteluihin vielä emotionaalisuuden ja kollektiivisuuden diskurssien lisäksi ammatillisuusdiskurssin, jolla korostetaan kokemuksen ja koulutuksen kautta tulevaa taitoa.

Hyvän yleisön todettiin myös kuuntelevan "tukevalla asenteella", "olevan hiljaa ja tukevan" sekä suhtautuvan muusikkoon "varauksettomalla hyväksynnällä" (Björkenheim h2004: 6-7; Evans h2006: 9; Toivanen h2004: 10). Kuunteleminen osaltaan osoittaa yleisön keskittyvän musiikkiin ja minimoivan muut toimensa. Huomio suuntautuu muusikkoihin samalla, kun sekä tuki että hyväksyntä viittaavat ajatukseen, että muusikko hyväksytään omana itsenään. Keskimmäiseen lainaukseen tosin sisältyy mielenkiintoinen ristiriita siitä, kuinka yleisö voi samanaikaisesti sekä tukea että olla hiljaa. Kommentin ajatuksena luultavasti onkin, että yleisö suuntaa huomionsa esiintyjiin ja osoittaa arvostustaan keskittymällä musiikkiin välttäen samalla liiallista melua.

Useammassa haastattelussa korostettiin sitä, että optimaalisessa esiintymispaikassa yleisö kuunteli eikä taustamelua ollut. Lontoolainen haastateltava totesi humoristisesti naureskellen, että hän "sieti" keikan aikana kuiskailua, mutta hiemankin enemmän melua niin yleisö oli "hemmetti vainaa" ja hän huusi näille "Ulos!". Haastattelussa kävi myös ilmi, että muusikko ei saisi olla liian herkkä yleisö käyttäytymiselle. (Kaldestad h2006: 9; Kürmayr h2006: 13; Lapthorn h2006: 18.) Kommentti 
osoittaa, että muusikon tulee sietää tietty määrä melua, mutta sananvalinta paljastaa sen että muusikko ei välttämättä pidä tästä itse. Kuiskailuun viittaaminen taas antaa ymmärtää, että yleisö puhuu hiljaisesti ja pyrkii minimoimaan melun kokonaismäärän.

Samanlaisia painotuksia löytyi myös IPA:ta käytettäessä. Muusikot korostivat toistuvasti tunnetta kuunnelluksi tulemisesta. Analyysi osoitti muusikoiden olevan sensitiivisiä yleisön mielialalle ja keskittymisen asteelle. Hyvän esityksen aikana muusikolle jää merkityksellinen tunne siitä, että häntä on kuultu ja hän on jättänyt jälkensä yleisön mieleen. (Evans h2006: 9; Paakki h2006: 9, 10, 20; Parker h2006: 9; Savolainen h2005; Uotila h2004: 2.)

Yleisöstä puhuminen toi esille myös ajatuksen kontaktin luomisesta:

Mutta minä olen erilainen, en välitä pätkääkään... Minä en välitä. Minä saan saman tunteen vaikka en soittaisikaan yleisön edessä. Mutta yleisö auttaa, koska sinä olet... Loppujen lopuksi sinä yrität kuitenkin jakaa sieluasi sen kautta... Minä yritän jakaa itsestäni muille ihmisille musiikkini kautta. Eikö niin? (Janisch h2006: 8, oma käännös.)

Tämä kommentti sisältää mielenkiintoisen ristiriidan. Ensin muusikko toteaa, että hän ei välitä yleisöstä ja näkee tässä eroavansa muista muusikoista. Voidaankin olettaa, että kyseisen muusikon rooli basistina asettaa hänet erilaiseen asemaan kuin esimerkiksi eturivin solistin. Lainauksen loppuosa taas viittaa ajatukseen oman sielunsa ja ajatustensa jakamisesta yleisölle musiikin kautta. Pohjimmaisena on siis kuitenkin tarve luoda syvempi kontakti ja jakaa omia ajatuksiaan muille. Tämä halu ja tunne itsensä jakamisesta tekevät esiintymisestä merkityksellisempää kuin yksin soittamisesta. Kontaktin ja yhteyden hakemisen korostaminen nostaa esille kollektiivisuuden diskurssin. Haastattelussa kävi ilmi, että muusikko hakee yleisön hyväksyntää, yhteyden tunnetta ja kokemusta, että on koskettanut yleisöä (Janisch h2006: 7). Yleisöllä on oma roolinsa tässä kaikessa. Yhteyden tunteen voidaan olettaa syntyvän yleisön huomiosta ja keskittymisestä sekä kappaleiden aikana että niiden välillä. Tämä liittyy yleisöltä saatavaan palautteeseen.

Eräs toinen muusikko nosti esille palautteen merkityksen todeten, että esitykseen vaikutti se mitä hän sai takaisin yleisöltä. Tässä yhteydessä muusikko korosti yleisön näkemisen tärkeyttä. Kyseinen muusikko selitti myös yleisön voivan vaikuttaa muusikon mielialaan. Hän totesi, että hänellä saattoi olla todella huono ilta, mutta jos hän kykeni saavuttamaan muutaman ihmisen yleisössä jotka nauttivat olostaan 
ja hänen soitostaan, hänen mielialansa parani ja hän kykeni soittamaan paremmin. (Henshaw h2006: 11.)

Muusikko siis seuraa yleisön reaktioita ja käytöstä varsin intensiivisesti. Ilmeistä kommentissa on myös se miten suoranaisesti yleisö kykenee vaikuttamaan muusikon tunteeseen ja esitykseen, eikä tähän vaadita edes koko yleisön osallistumista. Yleisön vaikutus muusikkoon näyttäisikin olevan ainakin joidenkin muusikkojen kohdalla varsin suuri. Avron White (1987: 206) onkin todennut muusikon saattavan kokea soolon jälkeisten suosionosoitusten puuttumisen jopa henkilökohtaisena loukkauksena, kun taas hyvät aplodit soolon jälkeen saattavat muuttaa muusikon huonon mielialan jälleen hyväksi.

IPA:n kautta tulivat esille myös tunteen ja tuntemusten merkityksen yleisön ja muusikon välisessä vuorovaikutuksessa. Haastatteluissa korostettiin kuinka tärkeää on tuntea yleisön kuuntelevan ja huomautettiin kuinka yleisön asenteen saattoi aistia (Kürmayr h2006: 15; Lapthorn h2006: 19; Savolainen h2005: 13; Uotila h2004: 2). Tällaiset lausahdukset osoittavat, että muusikko kykenee tuntemaan yleisön kehossaan. Muusikko on tietoinen yleisön luomasta ilmapiiristä kehonsa kautta. Kontakti yleisöön on siis myös kehollista.

Diskurssianalyysin kautta esille nousi myös ajatuksen mentaalisesta kontaktista, jossa esiintyjän sielu koskettaa yleisöä. Eräs haastateltava totesi, että vaikka edessä olisi yleisö joka ei reagoi, pystyy muusikko useimmiten löytämään yleisöstä muutaman yksilön joiden kanssa pystyy luomaan kontaktin. Spottien käydessä muusikon silmiin niin, että hän ei kyennyt näkemään yleisöä, muusikko luotti kuulemaansa. Useampi haastateltava myös totesi seuraavansa yleisön reaktioita sekä yleisön silmistä kuin heidän verbaalisesta osallistumisestaan. Eräs muusikko mainitsi myös tanssimisen palautteen muotona. Tanssivat ihmiset pystyivät toimimaan "induktiivisesti" tarjoamalla sekä rytmistä informaatiota että fyysisen sidoksen muusikoiden ja muusikkojen välille. (Björkenheim h2005: 6-7; Janisch h2006: 7; Sarath h2006: 8; Savolainen h2005: 13.) Muusikko on siis hyvin tietoinen yleisöstään ja kiinnittää huomiota kaikenlaiseen - visuaaliseen, auditiiviseen ja sensitiiviseen - yleisöstä tulevaan palautteeseen. Yleisön tanssiessa tilanteesta tulee myös fyysisesti molempien osapuolisen luomus.

Muusikoilla oli myös varsin suuri tarve tuntea yhteyttä yleisöönsä. IPA:n käytön kautta oli selvää, että muusikot haluavat tuntea tulleensa hyväksytyiksi ja arvostetuiksi yleisön silmissä. Muusikot etsivät työnsä kautta kunnioitusta. Haastattelemani muusikot myös sanoivat tuntevansa mielihyvää ja iloa, kun yleisö osallistuu 
ja osoittaa arvostustaan. (Garnett h2004: 10; Janisch h2006: 7, 8; Kürmayr h2006: 13; Lintinen h2005: 4, 5, 7; Savolainen h2005: 13.) Voidaankin todeta, että arvostus ja hyväksyntä vahvistavat muusikoiden päämäärän tunnetta ja tukee tunnetta oman työn merkityksellisyydestä. Hyväksyntä toimii palautteena kannustaen muusikkoja jatkamaan. Hyväksyntä ja arvostus myös rikkovat yleisön ja esiintyjien välisen raja-aidan, luoden tilan jossa molemmat osapuolet osallistuvat esityksen luomiseen. Yhteyden tunne ylittää esiintyjän yksilöllisyyden ja korostaa positiivista tunnetta. (Garnett h2004: 10.)

\section{Keskusteluja kaupallisuudesta ja yleisön miellyttämisestä}

Keskusteluissa osoitettiin myös se, että muusikko ei saisi odottaa aina esiintyessään parasta mahdollista tunnelmaa. Haastatteluissa muun muassa todettiin, että "muusikon tehtävä on tuottaa kuulijoille sitä musiikkia". Tästä syystä muusikon omien tunteiden tulisi olla toissijaisessa asemassa. (Toivanen h2004: 9-10.) Tämä kommentti osoittaa, että muusikon tehtävänä on tuottaa palveluja yleisölle ja tästä johtuen yleisöllä tulisi olla keskeinen rooli muusikon mielessä. Työstä ei tulisi odottaa nauttivansa joka ikinen keikka, sillä työ on työtä niin muusikolle kuin tilintarkastajallekin. Tällaiset ajatukset käyttävät hyväkseen ammatillisuusdiskurssia.

Edellisen lausahduksen kaltaisia kommentteja oli nähtävissä myös muiden muusikoiden puheissa. Eräs haastateltava totesi, että muusikon tulisi etsiä ratkaisuja ottaen huomioon kyseisen hetken ja yleisön. Muusikko ei myöskään saisi asennoitua esiintymiseen niin, että hän soittaa "omaa musiikkiaan" yleisölle.

\footnotetext{
Se ei oo et me soitetaan meidän musiikki niille, vaan et se kokemus on et lähinnä et: "Aha! Tää on meille [tämä] musiikki, meidän musiikki." Tää on se... Me olemme täällä kuuntelemassa just tänä ilta ja se ei toistu koskaan samanlaisena enää. Se on just meille osoitettu ja me ollaan nyt tavallaan osallistuneina siihen. (Björkenheim h2005: 1-2.)
}

Lainaus osoittaa, että muusikon pitäisi osoittaa musiikkinsa yleisölle. Esityksen pitäisi luoda yleisölle tunne, että tämä on heidän musiikkiaan, yhteistä jaettavaa, eikä vain esiintyjän suoritus. Olennaista lausahduksessa on myös viittaus yleisön aktiiviseen osallistumiseen. 
Edellä mainituista kommenteista huolimatta yleisöön suhtaudutaan yleisemmällä tasolla varsin ristiriitaisesti. Haastatteluissa nousi esille myös ajatus siitä, että heti kun keskustelu siirtyi siihen "mitä yleisö haluaa", siirryttiin puhumaan musiikin "businesspuolesta" jolla ei ole mitään tekemistä itse musiikin kanssa. Hieman samansuuntaisesti eräs toinen muusikko totesi, että esiintyjä joutuu miettimään kenelle hän itse asiassa soittaa. Tähän ajatukseen liittyi jako "viihdyttämisen" ja "itsekkään soittamisen" välillä. Muusikko totesi, että hän joutui miettimään mitä yleisö halusi kuulla, mutta ei halunnut tämän "tappavan" hänen soittotyyliään. (Kaldestad h2006: 8-9; Price h2003: 3.)

Ulkoiset vaatimukset, kuten yleisön odotukset, eivät liity luovuuteen ja taiteelliseen ilmaisuun, minkä muusikot yleensä näkevät olevan musiikkinsa keskeisin asia. Yleisön odotusten huomioiminen liitetään jazzin parissa varsin usein kaupallisuuteen, mikä nähdään useimmiten negatiivisena asiana. Kommentit myös osoittavat, että muusikko joutuu miettimään omia motiivejaan samoin kuin sitä, mitä yleisö haluaa ja mistä se maksaa. Viihdyttämiseen liittyy kulttuurisesti ajatus liiketoiminnasta ja luovuutta marginalisoivasta työnteosta sekä ajatus muusikon vastuusta yleisöä kohtaan. Muusikon täytyy tuottaa yleisön rahalle vastinetta. Tämä voidaan nähdä myös seuraavassa kommentissa:

\begin{abstract}
Sinä saatat ajautua sellaiseen tunteeseen, että sinun täytyy esiintyä tietyllä tavalla jotta sinua kuuntelevat ihmiset tulevat takaisin. Se on kuin keikan myymistä. Joskus se tarkoittaa itsensä myymistä. Se johtuu siitä että sinä haluat että he [yleisö] tulee takaisin tukemaan sinua niin että saat toisen keikan, tienaat rahaa ja ole suosittu. - - Niin, että ihmiset pitävät sinua hyvänä muusikkona, koska sinä soitat tavalla jota he voivat ymmärtää tai tunnistaa, sen sijaan että soittaisit itsellesi. (Garnett h2004: 3, oma käännös.)
\end{abstract}

Kyseinen lainaus osoittaa, että muusikon taloudellinen tilanne on riippuvainen yleisön ailahteluista. Muusikko joutuu tekemään kompromisseja ja myymään itsensä, tinkimään taiteellisista päämääristään, saadakseen yleisön saapumaan uudelleen. Lainauksen viimeinen lause antaa ymmärtää, että muusikko alentaa itsensä yleisön tasolle. Muusikko joutuu soittamaan yleisön ymmärtämällä sekä pitämällä tavalla ja tasolla, sillä yleisö mittaa muusikon taitoja juuri oman ymmärryksensä kautta. Koko lausahdus sisältää eräänlaisen jännitteen luovan ilmaisun ja yleisön odotusten - oman vision ja kompromissien - välillä. Kaupallisuuden ja itsekkyyden ajatukset tulivat esille myös IPA:ta käytettäessä, mutta pienemmässä mittakaavassa. 
Nämä keskustelut ovat hämmästyttävän samankaltaisia Beckerin (1951: 136) kohtaamien ajatusten kanssa. Hän on todennut että muusikot kokevat usein tarvetta valita oman taiteellisen näkemyksensä ja menestyksen välillä. Menestyminen vaatii hänen mukaansa usein sitä, että muusikosta tulee "kaupallinen". Tällä tarkoitetaan sitä, että muusikko joutuu soittamaan maksavan ei-muusikon toiveiden mukaisesti. Kaupallisuuden kautta muusikko samanaikaisesti uhraa kuitenkin usein muiden muusikkojen kunnioituksen ja toisinaan myös oman itsekunnioituksensa. Omien artistisien standardien noudattaminen merkitsee kuitenkin usein epäonnistumista laajemmassa yhteiskunnallisessa kontekstissa.

Samanlaisia mainintoja kaupallisuuden ja luovuuden välisestä rajanvedosta löytyy myös Berlinerin aineistosta (1994: 458) sekä Steward Gordonin oppaasta. Gordon toteaa, että klassisessa musiikissa useita vuosikymmeniä sitten oli vielä vallalla ajatus siitä, että kaupallisiin projekteihin osallistuminen oli "taiteellista prostituutiota" (Gordon 2006: 156). Sittemmin ajatukset ovat luultavasti lieventyneet, vaikkakin samansuuntaisia keskusteluja käydään yhä. Gordon toteaa kuitenkin, että muusikon tulisi löytää tasapaino yleisön saavuttamisen ja omien halujen ja kykyjen välillä. Hänen mukaansa jokaisen vakavan muusikon tulee määritellä itse missä hänen taiteellisen hyveellisyytensä rajat kulkevat. (Gordon 2006: 156-157.)

Kari Kurkela on myös kirjoittanut kaupallisuuden ja luovuuden välisestä jaosta. Kurkelan mukaan musiikin kentällä kaupallisuuden sijasta puhutaan yleensä hyväksynnästä ja huomiosta, jota tosin saattaa seurata myös rahallinen tuki. Kaupallisuudessa muusikko pyrkii aavistamaan yleisön toiveet ja kytkee niiden täyttämisen siihen mitä hän itse haluaa. Musiikista tulee välineellistä ja tekemisen motivaatio on ulkoinen. Kaupallisuutta voidaan pitää eräänlaisena selviytymisstrategiana. Luovuudessa musiikkia ei käytetä välineellisesti vaan lähtökohtana on musiikki itse. Muusikko on tällöin sisäisesti motivoitunut ja soittaminen itsessään on hänelle palkitsevaa. (Kurkela 1995: 85-86.)

Haastatteluissa tuotiin kuitenkin esille myös ajatus, että yleisön odotusten huomioimisen ohessa muusikon päämäärä oli "ylittää tämä huoli" menestymisestä ja "ei välittää pätkääkään siitä mitä he [yleisö] halusivat kuulla". Muusikko halusi lopulta vain saavuttaa optimaalisen soittokokemuksen, flow-tilan, ja nauttia musiikista. Osa yleisöstä pystyi muusikon mukaan todennäköisesti myös aistimaan muusikon saavuttaneen tämän tilan. (Kaldestad h2006: 9.) Kyseinen lausahdus osoittaa, että vaikka yleisön odotuksia ja motiiveita huomioidaan, ovat muusikon päämääränä viime kädessä yleisön tunteiden ulkopuolella olevat musiikilliset seikat ja oman motivaa- 
tion rakentaminen. Becker onkin todennut jazzmuusikon kokevan toisinaan suurta tarvetta yleisön toiveiden täyttämiseen. Yleisen, muusikkojen parissa vallitsevan ajatuksen mukaan tälle tunteelle ei saisi kuitenkaan antautua. (Becker 1951: 140.)

\section{Yleisön toissijaisuus ja "huonon" yleisön kohtaaminen}

Vaikka yleisön edessä soittamista pidettiin useimmiten varsin palkitsevana tilanteena, kävi haastatteluista myös ilmi, että yksin soittamisen nähtiin olevan ympäristöstä riippumatonta ja keskittymisen parempaa kuin yleisön edessä soitettaessa. Yleisön voidaan nähdä siis myös häiritsevän muusikon soittoa ja keskittymistä. Tämän lisäksi oli ilmeistä, että muusikot kokivat että tilanteen keskiössä tulisi olla itse musiikki ja "rakkaus musiikkiin". (Price h2003: 2; Uotila h2004: 4.) Tästä johtuen muusikko ei tarvinnut yleisöä nauttiakseen soittamisesta. Muusikko esiintyy koska hän rakastaa musiikkia ja siitä saamansa tunnetta. Keskittyminen suuntautuu siis itse musiikkiin yleisön jäädessä toissijaiseen rooliin. Haastatteluissa nousi esille myös ajatus siitä, että muusikon tulisi tiettyyn pisteeseen asti olla välittämättä yleisöstä ja liiallinen huomionhakuisuus yleisöltä pidettiin negatiivisena (Uotila h2004: 5).

Muutamat haastateltavat toivat esille myös ajatuksen siitä, että muusikoiden välinen vuorovaikutus ja kontakti olivat tärkeämpää kuin kontakti yleisöön. Esille nousi myös ajatus siitä, että muusikot soittivat ensisijaisesti itselleen. Kun muusikko oli tyytyväinen itseensä ja suoritukseensa, yleisö piti todennäköisesti myös lopputuloksesta. (Paakki h2006: 6; Trimble h2004: 5.) Tämän ajatuksen mukaan muusikot nauttivat soittamisesta enemmän heidän soittaessaan ensisijaisesti itselleen ja toisilleen. Tämä nostaa kuitenkin musiikin ja esityksen tasoa ja tarjoaa tätä kautta paremman kokemuksen myös yleisölle. Keskustelut yleisön toissijaisesta roolista ovat tästä johtuen varsin ristiriitaisia, sillä muusikoiden ensisijaisena huolenaiheena on aina musiikin laatu.

IPA:n kautta saatuna tärkeimpänä tuloksena, tähän aiheeseen liittyen, on juuri yleisön toissijaisuuden selittämiseen. Analyysin kautta kävi ilmeiseksi joidenkin muusikoiden jopa syvän pettymyksen tunteen suhteessa yleisöön. Tämä tunne osoittautuu tärkeäksi, kun tarkastelemme yleisön ristiriitaista asemaa esiintyjien mielessä. Pettymyksen tunteita voitiin nähdä muun muassa siinä miten eräät muusikot toivat esille yleisön käyttävän jazzia nykyään imagon rakentamiseen ja tietyille esiintymispaikoille tultiin näyttäytymään ja käyttämään rahaa. Haastatteluissa oli 
havaittavissa, että tällaista motivaatiota halveksuttiin ja se nähtiin vääränlaisena syynä jazzin kuunteluun. Tämä motivaatio ei syntynyt aidosta kiinnostuksesta tai tunnesidoksesta musiikkiin itseensä, vaan jazz nähtiin eräänlaisena "asusteena" (engl. accesorie), kuten eräs haastateltava asian ilmaisi. Samanlaista keskustelua käytiin myös suhteessa jazz festivaaleihin ja suomalaiseen juomakulttuuriin, kuten myös taustamusiikin soittamiseen. (Parker h2006: 17; Kürmayr h2006: 14; Lintinen h2005: 6; Savolainen h2005: 14.)

Haastattelemani muusikot puhuivat yleisön merkityksen yhteydessä myös "huonosta" yleisöstä. Joissakin haastatteluissa tuli esille esimerkiksi ajatus "kuolleesta yleisöstä". Tämä vertaus viittaa tilanteeseen jossa muusikko ei saa kontaktia yleisöön tai yleisö ei reagoi mihinkään mitä muusikko tekee. Yleisö on siis paikalla, muttei osallistu. Eräs muusikko myös totesi yleisön jäykkyyden heijastuvan esiintyjiin. (Janisch h2006: 7; Toivanen h2004: 9.) Myös Berliner (1994: 464) puhuu kuolleesta yleisöstä ja toteaa tämän tunteen johtuvan yleensä yleisön kykenemättömyydestä kannustaa muusikkoja oikein. Muusikot kykenevät myös havaitsemaan yleisön negatiivisen asenteen jo etukäteen. Haastatteluissa tuotiin esille myös se, että klubin huonon ilmapiirin pystyi aistimaan sinne kävellessään. Tällainen vastustus vaikutti muusikon soittamiseen. (Garnett h2004: 11.) Tämän tyyppiset kommentit osoittavat yleisön luovan ilmapiirin johon muusikko vastaa. Ilmapiiri rakentuu yleisön odotusten ja motivaation kautta.

Muusikon ja yleisön välinen vuorovaikutus voidaan kokea myös negatiiviseksi. Eräässä haastattelussa kävi ilmi, että pienessä yleisössä yksilöt saivat suuremman vallan. Pienessä tilassa soitettaessa yleisössä istuvat yksilöt pystyivät "heijastamaan omaa tahtoaan ja yksilöllisyyttä" esiintyjään. (Garnett h2006: 20.) Tämä ei tietenkään automaattisesti ole negatiivista, vaan saattaa tuntua muusikosta varsin positiiviselta vuorovaikutukselta. Jos yleisössä istuva yksilö heijastaa omaa tahtoaan kuitenkin liian vahvasti esiintyjään pyrkien tätä kautta vaikuttamaan musiikkiin, saattaa kokemus muuttua negatiiviseksi. Yksilön odotukset ja asenteet saavat liian suuren arvon ja ottavan näin vallan esityksessä. Muusikko saattaakin kokea toisinaan olonsa rennommaksi täysin suoran katsekontaktin puuttuessa esimerkiksi isommilla lavoilla.

Haastatteluissa keskusteltiin myös siitä miten jazzin historia on täynnä tapauksia joissa muusikot ovat kokeneet että yleisö ei ole ymmärtänyt tai arvostanut esiintymisessä soitettua musiikkia, vaikka paikalla ovat olleet maailman parhaat muusikot. Tästä syystä yleisöä ei tule yliarvioida. (Lintinen 2005: 4-5.) Muusikon kokema yleisön arvaamattomuus ja ymmärtämättömyys saavat muusikon kääntymään si- 
säänpäin ja asettamaan yleisön toissijaiseen asemaan. Kommenttiin sisältyy myös osaltaan musiikin sisältämä arvokkuus muusikolle itselleen. Kun yleisö ei jaa samoja arvoja, se käyttäytyy useimmiten muusikon mielestä epäsopivasti. Muusikko saattaa tällöin kokea kouluttautuneensa ja harjoitelleensa vuosikymmeniä kohdatakseen keikoillaan vain välinpitämättömyyttä, jolloin muusikon työn mielekkyys kyseenalaistuu. Yleisön yliarvioimisen välttelyyn liittyy myös ajatus, että muusikon tulee etsiä tukea vain omasta itsestään ja kanssamuusikoista, jotka ymmärtävät musiikin todellisen arvon.

Edellä mainitun kommentin tyyppisiä esimerkkejä löytyy myös kirjallisuudesta. Berliner kirjoittaa eräästä Stan Getzin keikasta, jolla lavan edessä olevassa pöydässä istuva nainen oli hyvin kovaan ääneen selittänyt ystävänsä ostamasta minkkiturkista. Tarjoilija oli tullut huomauttamaan, että nainen häiritsee esitystä ja lähipöytien asiakkaita. Nainen oli ärsyyntynyt ja todennut miksi hänen pitäisi olla hiljaa johon tarjoilija oli todennut, että Stan Getz soitti juuri sooloaan. Nainen oli huutanut takaisin: "Kuka on Stan Getz?" (Berliner 1994: 457-8.) Tällaiset tarinat asettavat jopa parhaimmat jazzmuusikot varsin alisteiseen asemaan suhteessa yleisöön.

Negatiiviset tilanteet ja "huono" yleisö vähentävät myös muusikoiden motivaatiota ja lisäävät tyytymättömyyttä omaan työ- ja sosiaaliseen tilanteeseen. Tämä on nähtävissä esimerkiksi kommentissa, jossa haastateltava kuvaili erästä keikkaansa jossa hän oli soittamassa taustamusiikkia cocktailtilaisuudessa. Hän totesi soittaessaan paljastavansa oman rakkautensa musiikkiin. Kesken erään kappaleen oli eräs herra tullut pyytämään häntä lopettamaan jotta voisi pitää puheen. (Kaldestad h2006: 14.) Tällaisissa tilanteissa musiikki on toissijaisessa asemassa. Elävänä soitettu musiikki rinnastuu levyltä tulevaan musiikkiin, joka voidaan katkaista koska tahansa, jopa keskellä kappaletta. Musiikkia käytetään tällaisissa tilanteissa lähinnä prestiisin luomiseen, sillä rahaa on käytetty muusikoiden palkkaamiseen levyjen sijasta, mutta heitä kohdellaan kuin palvelijoita.

\section{Pohdintaa}

Yleisöllä ja yleisön käytöksellä on varsin moninainen ja hienosyinen merkitys muusikoille. Monille jazzmuusikoille soittamisen merkityksellisyys nousee juuri elävän musiikin soittamisesta ja yleisön kohtaamisesta. Muusikoille esitys on tilanne jonka yleisö ja muusikot luovat yhdessä. Kyse on vuorovaikutuksesta jossa sekä esiinty- 
jällä että yleisöllä on oma roolinsa. Kun molemmat tunnistavat tämän, ovat mahdollisuudet hyvän ja merkityksellisen esiintymistilanteen syntymiselle valmiit. Kuten Paul Berliner on todennut, sivistynyt yleisö on tietoinen siitä, että heillä on osuus musiikillisen kokonaisuuden luomisessa. Musiikin tunteva yleisö voi Berlinerin mukaan jopa vaikuttaa muusikoiden esiintymiskäytäntöihin. (Berliner 1994: 470.)

Muusikoille itselleen tärkeäksi nousivat yleisön keskittyminen, asenne ja motivaatio. Esille nousi ajatus yleisön asenteen aistimisesta ja kokemisesta muusikon kehon kautta. Tärkeää muusikoille tämän tarkastelun puitteissa näyttäisikin olevan myös tunne kuunnelluksi ja hyväksytyksi tulemisesta. Optimaalisella yleisöllä nähtiin olevan jonkinlainen emotionaalinen sidos esitettyyn musiikkiin. Muusikot näyttäisivät myös hakevan aktiivisesti kontaktia yleisöönsä.

Haastatellut muusikot myös lukivat yleisön suhtautumista varsin pienistä eleistä ja korostivat niin auditiivista, visuaalista kuin sensitiivistäkin kontaktia yleisöönsä. Kaikenlaiset vihjeet yleisön mielentilasta nähtiin tärkeiksi. Varsin pienet ja huomaamattomat eleet voivat siis vaikuttaa muusikon kokemukseen. Tämä käy esille muun muassa Paul Berlinerin (1994: 464) eräästä lainauksesta, jossa muusikko toteaa yleisön olleen "tarpeeksi mukava" kun se oli taputtanut kaikkein kappaleiden jälkeen, mutta hän pystyi tuntemaan että yleisö ei oikeasti kuunnellut.

Muusikon työskentely on usein taiteilua näiden kahden lähestymistavan - taiteellisen ja kaupallisen - välillä. Vaikka haastatteluissa korostettiin myös tavallisen työnteon ajatusta ja yleisön toiveiden huomioimista, pyrkivät muusikot pääasiallisesti kuitenkin toteuttamaan omia visioitaan. Yleisön halujen täydellinen seuraaminen nähtiin omien päämäärien myymisenä, vaikka usein jouduttiinkin miettimään mistä yleisö oli valmis maksamaan. Omien visioiden toteuttamisen nähtiin kuitenkin lisäävän musiikin laatua ja vaikuttavan täten myös yleisön kokemukseen positiivisesti. Raja kaupallisen ja taiteellisen välillä on kuitenkin edelleen olemassa ja muusikot näyttäisivät arvioivan ja arvottavan myös toistensa työskentelyä suhteessa tähän rajanvetoon.

Musiikin asemaa yleisön mielessä myös kyseenalaistettiin ja musiikin välineellistämistä imagon jatkeeksi kritisoitiin. Analyysi myös osoitti joidenkin muusikoiden pettyneen yleisöönsä. Negatiiviset kokemukset ja muusikoiden mielestä "huono" yleisö vähentävät muusikoiden työskentelymotivaatiota lisäten samalla muusikon tyytymättömyyttä. Osittain tästä syystä muusikoiden ensisijaisena keskittymisen kohteena onkin musiikki itse ja yleisön roolia ja merkitystä pyritään minimoimaan. Tulee kuitenkin huomata, että myös keikkojen taustalla vaikuttavalla organisaatiol- 
la - klubilla ja muilla järjestäjillä - on oma vastuunsa yleisön käyttäytymistapojen luomisessa.

Kaikesta huolimatta yleisöllä on kuitenkin varsin suuri rooli esiintymisen rakentamisessa ja arvostavan yleisön kohtaaminen nähdäänkin erityisen antoisana tilanteena. Voidaankin todeta, että jazz todella on hetken taidetta. Jokainen live-esitys on ainutlaatuinen, ei pelkästään improvisaation tähden vaan myös yleisöstä - sen motivaatiosta ja intentioista - johtuen.

\section{Viitteet}

1 Haastatteluihin viittaavien lähdeviitteiden perässä oleva numero viittaa transkription sivuun.

2 IPA:n kautta saaduissa tuloksissa ei paikanneta yksittäistä puhujaa. Yhtenäisyyden vuoksi on muusikoiden nimet jätetty mainitsematta itse tekstissä ja ne näkyvät vain kappaleen lopussa olevassa lähdeviitteessä. Heittomerkkien sisällä lauseet olevat lainauksia haastatelumateriaalista.

\section{Lähteet}

\section{Haastattelut}

Kaikki haastattelut Elina Hytösen tekemiä.

Kaikki nauhat ja transkriptiot haastattelijan hallussa.

Björkenheim, Raoul. 25.2.2005. Helsinki.

Evans, Sandy. 1.7.2006. Puhelinhaastattelu. Sydney, Australia.

Garnett, Alex. 9.1.2004. Savitaipale.

Garnett, Alex. 30.9.2006. Lontoo, Englanti.

Henshaw, Elliott. 28.9.2006. Lontoo, Englanti.

Janisch, Michael. 30.9.2006. Lontoo, Englanti.

Kaldestad, Steve. 29.9.2006. Lontoo, Englanti.

Kürmayr, Gunther. 28-29.9.2006. Lontoo, Englanti.

Lapthorn, Tim. 30.9.2006. Lontoo, Englanti.

Lintinen, Kirmo. 10.7.2005. Helsinki.

Paakki, Riitta. 22.8.2006. Helsinki.

Parker, Evan. 28.9.2006. Lontoo, Englanti.

Price, Larry. 14.11.2003. Lappeenranta.

Sarath, Ed. 4.12.2006. Ann Arbor, Michigan, USA.

Savolainen, Jarmo. 31.1.2005. Helsinki.

Toivanen, Pekka. 12.10.2004. Helsinki.

Trimble, Ted. 29.10.2004. Joensuu.

Uotila, Jukkis. 12.10.2004. Helsinki. 


\section{Kirjallisuus}

Becker, Howard S. (1951) "The Professional Dance Musician and His Audience". The American Journal of Sociology 57: 2, ss. 136-144.

Berliner, Paul F. (1994) Thinking in Jazz: The Infinite Art of Improvisation. Chicago \& London: The University of Chicago Press.

Butler, Jennifer L. \& Baumeister, Roy F. (1998) "The Trouble With Friendly Faces: Skilled performance with a supportive audience". Journal of Personality and Social Psychology 75: 5, ss. 1213-1230.

Csikszentmihalyi, Mihaly (2002) Flow: The classic work on how to achieve happiness. $2^{\text {nd }}$ edition. London: Rider.

Gordon, Stewart (2006) Mastering the art of performance: A primer for musicians. Oxford \& New York: Oxford University Press.

Helm, Everett (1970) Composer, Performer, Public: A Study in Communication. Florence: Leo S. Olschki.

Hytönen, Elina (2008) "Jazzin paikka ja tila - esiintymistilojen tarkastelua". Musiikki 3-4: 38, ss. 85-101.

Jeddeloh, Steven C. (2003) Chasing Transcendence: Experiencing "magic moments" in jazz improvisation. Fielding Graduate Institute, University of Michigan. Unpublished Dissertation for the degree of Doctor of Philosophy.

Johnson, Richard; Chambers, Deborah; Raghuram, Parvati \& Tincknell, Estella (2004) The Practise of Cultural Studies. London: Sage Publications.

Kurkela, Kari (1995) "Yksityisen ja yhteisen rajalla: Musiikinesittämisen emotionaalisista ja kognitiivisista ulottuvuuksista". Esiintyjä - taiteen tulkki ja tekijä. Toim. Raija Ojala. Helsinki: WSOY. Ss. 77-115.

Niemi, Irmeli (1995) “Kallioluolista kadunkulmaan: Esittäminen - osa ihmisenä olemista". Esiintyjä-taiteen tulkki ja tekijä. Toim. Raija Ojala. Helsinki: WSOY. Ss. 11-30.

Potter, Jonathan; Stringer, Peter \& Wetherell, Margaret (1984) Social Texts and Context: Literature and Social Psychology. London: Routledge \& Kegan Paul.

Potter, Jonathan \& Wetherell, Margaret (1987) Discourse and Social Psychology: Beyond Attitudes and Behaviour. London: Sage Publications.

Smith, Jonathan A. (1996) "Beyond the Divide between Cognition and Discourse: Using Interpretative Phenomenological Analysis in Health Psychology". Psychology \& Health 11: 2, ss. 261-271.

Smith, Jonathan A. (1999) “Towards a Relational Self: Social Engagement During Pregnancy and Psychological Preparation for Motherhood". British Journal of Social Psychology 38, ss. 409-426.

Smith, Jonathan A. \& Osborn, Mike (2003) "Interpretative Phenomenological Analysis". Qualitative Psychology: A Practical Guide to Research Methods. Toim. Jonathan A. Smith. London, Thousand Oaks, New Delhi: Sage Publications. Ss. 51-80.

White, Avron Levine (1987) "A Professional Jazz Group". Lost in Music: Culture, Style and the Musical Event. Toim. Avron Levine White. London \& New York: Routledge \& Kegan Paul. Ss. 191-219.

Willig, Carla (2003) “Discourse analysis”. Qualitative Psychology: A Practical Guide to Research Methods. Toim. Jonathan A. Smith. London, Thousand Oaks, New Delhi: Sage Publications. Ss. 159-183. 